http://dx.doi.org/10.11646/phytotaxa.161.2.7

\title{
Introducing Chaetothyriothecium, a new genus of Microthyriales
}

\author{
SINANG HONGSANAN ${ }^{1,2}$, PUTARAK CHOMNUNTI ${ }^{1,2}$, PEDRO W. CROUS $^{3}$, EKACHAI CHUKEATIROTE ${ }^{1,2}$, \\ KEVIN D. HYDE ${ }^{1,2}$ \\ ${ }^{I}$ Institute of Excellence in Fungal Research, Mae Fah Luang University, Chiang Rai, 57100, Thailand \\ ${ }^{2}$ School of Science, Mae Fah Luang University, Chiang Rai, 57100, Thailand \\ ${ }^{3}$ CBS-KNAW, Fungal Biodiversity Centre, Uppsalalaan 8, 3584 CT Utrecht, The Netherlands \\ Corresponding author: Kevin D. Hyde.e-mail address: kdhyde3@gmail.com
}

\begin{abstract}
The order Microthyriales comprises foliar biotrophs, epiphytes, pathogens or saprobes that occur on plant leaves and stems. The order is relatively poorly known due to limited sampling and few in-depth studies. There is also a lack of phylogenetic data for these fungi, which form small black spots on plant host surfaces, but rarely cause any damage to the host. A "Microthyriaceae"-like fungus collected in central Thailand is described as a new genus, Chaetothyriothecium (type species Chaetothyriothecium elegans sp. nov.). Phylogenetic analyses of LSU gene data showed this species to cluster with other members of Microthyriales, where it is related to Microthyrium microscopicum the type of the order. The description of the new species is supplemented by DNA sequence data, which resolves its placement in the order. Little molecular data is available for this order, stressing the need for further collections and molecular data.
\end{abstract}

Key words: foliar epiphytes, Micropeltidaceae, Microthyriaceae, phylogenetic analyses

\section{Introduction}

Fungal foliar epiphytes are a polyphyletic group found on plants worldwide (Schoch et al. 2009, Li et al. 2011, Wu et al. 2011, Hyde et al. 2013). The group has been poorly studied, few cultures are available in culture collections, and DNA sequence data is lacking in public databases. One major contributing factor is the fact that many of these species are obligate parasites and cannot be cultured (Wu et al. 2011).

The order Microthyriales comprises foliar epiphytes, which mainly form small, inconspicuous, black spots on host leaves. The spots consist of flattened thyriothecia with various ostiole forms, while the basal wall is usually poorly developed. Asci are bitunicate, fissitunicate, saccate to subglobose, obclavate to fusiform, or rarely cylindro-clavate, and ascospores are uni- to multi-septate, and hyaline or brown (Arnaud 1918, Luttrell 1973, von Arx \& Müller 1975, Barr 1987, Kirk et al. 2008, Wu et al. 2011, Hyde et al. 2013). Little molecular data is presently available for the order and in an overview of Dothideomycetes (Schoch et al. 2009), Microthyriales was represented by a single strain, Microthyrium microscopicum, as a long branch sister to Stomiopeltis betulae. More recently, Wu et al. (2011) added sequence data for three "Microthyriaceae"-like species_-Paramicrothyrium and Neomicrothyrium were introduced as new genera and Micropeltis zingiberacicola as a new species; molecular analysis indicated they can probably be placed in Microthyriales. Hyde et al. (2013) placed Microthyrium microscopicum (Microthyriaceae type species) and Stomiopeltis betulae (Micropeltidaceae) in Microthyriales, and the families Microthyriaceae and Micropeltidaceae were accepted based on morphological data. The family Microthyriaceae includes foliar biotrophs and saprotrophs, with easily removed thyriothecia comprising dark, mostly cuboid or angular cells, arranged in parallel rows from the prominent central ostiole to the periphery, and a poorly developed base. Asci are fusiform to cylindrical or elongate and ascospores are uniseptate and hyaline (Doidge 1942, Müller \& von Arx 1962, Luttrell 1973, Barr 1987, Hofmann \& Piepenbring 2006, Hofmann 2010, Wu et al. 2011, Hyde et al. 2013). Wu et al. (2011) recognized seven genera of Microthyriaceae, while a further 
smooth-walled. On PDA, mycelium growing very slowly, colonies reaching $1.5 \mathrm{~cm}$ diam after 30 days, raised, comprising raised dark grey mycelium, white to greyish at the margin and also partly covering colonies, surface of colonies velvety. Asexual state: not observed.

Material examined:- THAILAND. Nakhon Nayok Province: Khao Yai National Park, on dead leaves of Castanopsis sp., 16 June 2012, Narumon Tangtheerasunun (MFLU13-0091! - holotype, ex-type living culture = MFLUCC12-0399 $(\mathrm{MFU})=$ CPC $21375=$ CBS 136075).

\section{Discussion}

Chaetothyriothecium differs from other genera in the Microthyriales that have thyriothecial ascomata (Wu et al. 2011), because of the darkened rim surrounding the central ostiole, which is made up of long radiating setae. In other aspects, Chaetothyriothecium elegans is typical of Microthyriales in having thyriothecia comprising radiating cells but with a poorly developed base, ovoid bitunicate asci with short pedicels and bi-celled, hyaline ascospores. The phylogenetic analyses of LSU sequence data indicate that Chaetothyriothecium is a well resolved genus in Microthyriales.

There is a lack of sequence data for Microthyriales available in GenBank and this group is also morphologically relatively poorly studied. A putative strain of Microthyrium microscopicum, which represents the type of the order indicates that the Microthyriales is well resolved (Schoch et al. 2009, Wu et al. 2011, Hyde et al. 2013). Chaetothyriothecium elegans is related to Microthyrium microscopicum and Stomiopeltis betulae and can be included in Microthyriaceae as it is morphologically similar and this is supported in the phylogenetic analysis. It is important that more gene sequences are obtained for taxa in this order so that a natural classification can be obtained.

\section{Acknowledgements}

This study was supported by Mae Fah Luang University grant number 56101020032 to study Dothideomycetes in Thailand. The Mushroom Research Foundation, Thailand is acknowledged for a scholarship to SH.

\section{References}

Arnaud, G. (1918) Lés Asterinées. Annals d'École National d'Agriculture de Montpellier Série 2 16: 1-288.

Arx, J.A. von \& Müller, E. (1975) A re-evaluation of the bitunicate ascomycetes with key to families and genera. Studies in Mycology 9: 1-159.

Barr, M.E. (1987) New taxa and combinations in the Louculoascomycetes. Mycotaxon 29: 501-505.

Batista, A.C. (1959) Monografia dos fungos Micropeltaceae. Publicações Instituto de Micologia da Universidade do Recife 56: $1-519$.

Cai, L., Guo, X.Y. \& Hyde, K.D. (2008). Morphological and molecular characterization of a new anamorphic genus Cheirosporium, from freshwater in China. Persoonia 20: 53-58. http://dx.doi.org/10.3767/003158508x314732

Cai, L., Jeewon, R. \& Hyde, K.D. (2006) Phylogenetic investigations of Sordariaceae based on multiple gene sequences and morphology. Mycological Research 110: 137-150. http://dx.doi.org/10.1016/j.mycres.2005.09.014

Cai, L., Wu, W.P. \& Hyde, K.D. (2009) Phylogenetic relationships of Chalara and allied species inferred from ribosomal DNA sequences. Mycological Progress 8(2): 133-143.

http://dx.doi.org/10.1007/s11557-009-0585-5

Chomnunti, P., Schoch, C.L., Aguirre-Hudson, B., Ko-Ko, T.W., Hongsanan, S., Jones, E.B.G., Kodsueb, R., Phookamsak, R., Chukeatirote, E., Bahkali, A.H. \& Hyde, K.D. (2011) Capnodiaceae. Fungal Diversity 51: 103-134. http://dx.doi.org/10.1007/s13225-011-0145-6

Clements, F.E. \& Shear, C.L. (1931) Genera of fungi 2 Vol. i-vii. H.W. Wilson, USA, New York, 496 pp.

Doidge, E.M. (1942) South African Microthyriaceae. Bothalia 4: 273-344.

Hall, T.A. (1999) BioEdit: a user-friendly biological sequence alignment editor and analysis program for Windows 95/98/NT. Nucleic Acids Symposium Series 41: 95-98.

Hofmann, T.A. (2010) Plant parasitic Asterinaceae and Microthyriaceae from the Neotropics (Panama). PhD thesis, The 
Faculty of Biological Sciences at the J.W. Goethe-University Frankfurt am in, Germany, 408 pp.

Hofmann, T.A. \& Piepenbring, M. (2006) New records and host plants of fly-speck fungi from Panama. Fungal Diversity 22: 55-70.

Huelsenbeck, J.P. \& Ronquist, F. (2001) MRBAYES: Bayesian inference of phylogenetic trees. Bioinformatics 17(8): 754-755. http://dx.doi.org/10.1093/bioinformatics/17.8.754

Hyde, K.D., Jones, E.B.G., Liu, J.K., Ariyawansha, H., Boehm, E., Boonmee, S., Braun, U., Chomnunti, P., Crous, P., Dai, D.Q., Diederich, P., Dissanayake, A., Doilom, M., Doveri, F., Hongsanan, S., Jayawardena, R., Lawrey, J.D., Li, Y.M., Liu. Y.X., Lücking, R., Monkai, J., Nelsen, M.P., Phookamsak, R., Muggia, L., Pang, KL., Senanayake, I., Shearer, C.A., Wijayawardene, N., Wu, H.X., Thambugala, M., Suetrong, S., Tanaka, K., Wikee, S., Zhang, Y., Hudson, B.A., Alias, S.A., Aptroot, A., Bahkali, A.H., Bezerra, L.J., Bhat, J.D., Camporesi, E., Chukeatirote, E., Hoog, S.D., Gueidan, C., Hawksworth, D.L., Hirayama, K., Kang, J.C., Knudsen, K., Li, W.J., Liu, Z.Y., McKenzie, E.H.C., Miller, A.N., Nadeeshan, D., Phillip, A.J.L., Mapook, A., Raja, H.A., Tian, Q., Zhang, M., Scheuer, C., Schumm, F., Taylor, J., Yacharoen, S., Tibpromma, S., Wang, Y., Yan, J. \& Li, X. (2013) Families of Dothideomycetes. Fungal Diversity 63: 1313. http://dx.doi.org/10.1007/s13225-013-0263-4

Katoh, K., Asimenos, G. \& Toh, H. (2009) Multiple alignment of DNA sequences with MAFFT. Methods in Molecular Biology 537: 39-64. http://dx.doi.org/10.1007/978-1-59745-251-9_3

Kirk, P.M., Cannon, P.F., Minter, D.W. \& Stalpers, J.A. (2008) Ainsworth \& Bisby's dictionary of the fungi, $10^{\text {th }}$ edition. CAB International, Wallingford, UK, $428 \mathrm{p}$.

Li, Y.M., Haixia, Wu, Cheng, H. \& Hyde, K.D. (2011) Morphological studies in Doithideomycetes: Elsinoë (Elsinoaceae), Butleria and three excluded genera. Mycotaxon 115: 507-520. http://dx.doi.org/10.5248/115.507

Lumbsch, H.T. \& Huhndorf, S.M. (2010) Outline of Ascomycota-2009. Fieldiana Life Earth Science 1: 1-60.

Luttrell, E.S. (1973) Loculoascomycetes. In: Ainsworth, G.C., Sparrow, F.K. \& Sussman, A.S. (eds) The fungi. An advanced treatise. Academic Press, New York and London, pp. 135-219.

Müller, E. \& Arx, J.A. von (1962) Die Gattungen der didymosporen Pyrenomyceten. Beiträge zur Kryptogamenflora der Schweiz 11(2): 1-922.

Nylander, J.A.A., Wilgenbusch, J.C., Warren, D.L. \& Swofford, D.L. (2008) AWTY (are we there yet?): a system for graphical exploration of MCMC convergence in Bayesian phylogenetics. Bioinformatics 24: 581-583. http://dx.doi.org/10.1093/bioinformatics/btm388

Page, R.D.M. (2001) TreeView: Tree drawing software for Apple Macintosh and Windows. Available at http:// taxonomy.zoology.gla.ac.uk/rod/treeview.html

Pattengale, N.D., Alipour, M., Bininda-Emonds, O.R.P., Moret, B.M.E. \& Stamatakis, A. (2009) How many bootstrap replicates are necessary? LNCS 5541: 184-200.

Phillips, A.J.L., Alves, A., Pennycook, S.R., Johnston, P.R., Ramaley, A., Akulov A. \& Crous P.W. (2008) Resolving the phylogenetic and taxonomic status of dark-spored teleomorph genera in the Botryosphaeriaceae. Persoonia 21: 29-55. ttp://dx.doi.org/10.3767/003158508x340742

Rannala, B. \& Yang, Z. (1996) Probability distribution of molecular evolutionary trees: a new method of phylogenetic inference. Journal of Molecular Evolution 43: 304-311. http://dx.doi.org/10.1007/bf02338839

Schoch, C.L., Crous, P.W., Groenewald, J.Z., Boehm, E.W., Burgess, T.I., de Gruyter, J., de Hoog, G.S., Dixon, L.J., Grube, M., Gueidan, C., Harada, Y., Hatakeyama, S., Hirayama, K., Hosoya, T., Huhndorf, S.M., Hyde, K.D., Jones, E.B., Kohlmeyer, J., Kruys, A., Li, YM., Lucking, R., Lumbsch, H.T., Marvanova, L., Mbatchou, J.S., McVay, A.H., Miller, A.N., Mugambi, G.K., Muggia, L., Nelsen, M.P., Nelson, P., Owensby, C.A., Phillips, A.J., Phongpaichit, S., Pointing, S.B., PujadeRenaud, V., Raja, H.A., Plata, E.R., Robbertse, B., Ruibal, C., Sakayaroj, J., Sano, T., Selbmann, L., Shearer, C.A., Shirouzu, T., Slippers, B., Suetrong, S., Tanaka, K., Volkmann-Kohlmeyer, B., Wingfield, M.J., Wood, A.R., Woudenberg, J.H., Yonezawa, H., Zhang, Y. \& Spatafora, J.W. (2009) A class-wide phylogenetic assessment of Dothideomycetes. Studies in Mycology 64: 1-15. http://dx.doi.org/10.3114/sim.2009.64.01

Silvestro, D. \& Michalak, I. (2012) RaxmlGUI: a graphical front-end for RAxML. Organisms Diversity and Evolution 12: 335337. http://dx.doi.org/10.1007/s13127-011-0056-0

Thompson, J.D., Gibson, T.J., Plewniak, F., Jeanmougin, F. \& Higgins, D.G. (1997) The Clustal X Windows interface: flexible strategies for multiple sequence alignment aided by quality analysis tools. Nucleic Acids Research 25: 4876-4882. http://dx.doi.org/10.1093/nar/25.24.4876

Wu, X., Schoch, C.L., Boonmee, S., Bahkali, A.H., Chomnunti, P., Hyde, K.D. (2011) A reappraisal of Microthyriaceae. Fungal Diversity 51(1): 189-248. http://dx.doi.org/10.1007/s13225-011-0143-8

Zhaxybayeva, O. \& Gogarten, J.P. (2002) Bootstrap, Bayesian probability and maximum likelihood mapping: exploring new tools for comparative genome analyses. BMC Genomics 3: 4. 